\title{
Microscopic Contributions to the Understanding of Glassy-winged Sharpshooter Feeding Behavior and Host-plant Interaction
}

\author{
Thomas Freeman,* James Buckner,** Roger Leopold,** Scott Payne,* and Jayma Moore* \\ *Electron Microscopy Center, North Dakota State University, 1307 N. 18 St., Fargo, ND 58105 \\ **Biosciences Research Laboratory, USDA-ARS, Fargo, 1605 Albrecht Blvd., Fargo, ND 58105
}

The glassy-winged sharpshooter (GWSS), Homalodisca coagulata, is a significant threat to many economically important crops because it vectors the bacterial pathogen Xylella fastidiosa, which causes Pierce's disease in grapes, variegated chlorosis in citrus, and leaf scorch in oleander and almond. Different strains of the bacteria cause diseases of avocados, peaches, plums, apricots, cherries, alfalfa, and many other trees and ornamentals. The GWSS (Fig. 1) is known to feed on more than 100 species of plants. Knowledge of mouthpart structure is necessary to understand the mechanics of GWSS stylet penetration and stylet movement through host-plant tissues. Thus, we employed a variety of microscopic techniques to describe the morphology and ultrastructure of the sharpshooter mouthparts, determine the characteristics of stylet penetration, reveal the pathway of the stylets from the epidermis of the host plant to the xylem tissue, and establish the ultrastructural damage the stylets cause to host-plant cells.

Both scanning and transmission electron microscopy were used to describe the sharpshooter mouthparts. Sensory structures were found along the lateral surface and at the distal end of the labium (Fig. 2), and within the labial groove. The rigid mandibular stylets (Fig. 3) taper to sharp points and are elaborately sculptured at the tips and along the borders. A dendritic canal traverses the interior of each mandible. The maxillary stylets (Fig. 4) interlock with each other, forming a smooth hollow tubular structure with noticeable dentitions near the tip of each stylet. The ducts and canals are evident when the stylets are viewed in cross section. Knowledge of mouthpart structure is necessary to understand the mechanics of GWSS stylet penetration and stylet movement through host-plant tissues.

Brightfield and scanning confocal light microscopy, SEM, and TEM each contributed to the study of stylet penetration and salivary sheath structure. Both nymphs and adult sharpshooters form salivary sheaths as the stylets penetrate into host tissues. The salivary sheaths may be simple (Fig. 5) or highly branched (Fig. 6). Even though this insect is considered to be an exclusive xylem feeder, microscopic studies reveal that only about $50 \%$ of all probes terminate in the xylem. Salivary sheath material is frequently found plugging vessel elements (Fig. 7), restricting water translocation.

The GWSS is capable of rapidly penetrating even woody stems with its mouthparts. Transmission electron microscopy has demonstrated that the stylets easily penetrate not only the cellulose walls of parenchyma but also the thick lignified wall of fibers and tracheary elements. The rigid vesselelement walls are not simply penetrated but are completely fractured (Fig. 8), disrupting water movement within the host plant.

A combination of microscopic techniques has provided essential data for researchers studying multiple aspects of glassy-winged sharpshooter biology and control in a continuing effort to minimize the economic impact of this insect. 


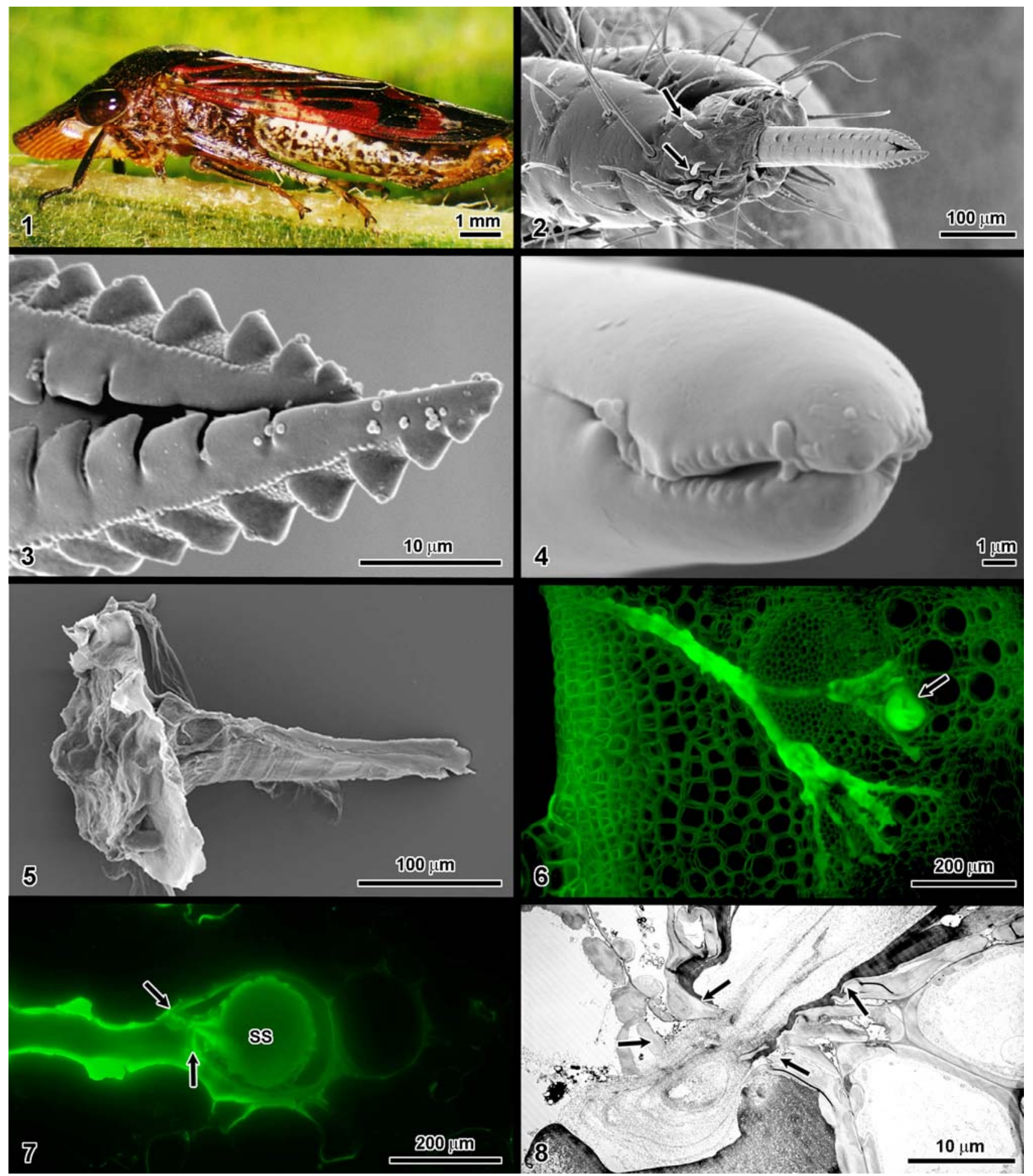

FIG. 1. Adult glassy-winged sharpshooter in feeding position on abaxial surface of host-plant leaf.

FIG. 2. Sensory structures (arrows) along sharpshooter labium. FIG. 3. Mandibular stylet tips.

FIG. 4. Maxillary stylets with sensory dentitions. FIG. 5. Complete unbranched salivary sheath.

FIG. 6. Highly branched salivary sheath in host-plant tissue. Note plugged vessel element (arrow).

FIG. 7. Vessel element plugged with salivary sheath material (ss). Note vessel-element wall

(arrows). FIG. 8. Vessel-element walls (arrows) ruptured by stylet penetration. 